\title{
Price and Income Elasticities of Fuel Demand in Kosova
}

\author{
By Valon Kastrati ${ }^{1}, \mathrm{PhD}$ candidate
}

\begin{abstract}
Gasoline and diesel are the main sources of fuel required for modern life and transportation, and the adjustment of gasoline and diesel prices has become a major public issue. The drastic fluctuations in recent international oil prices have affected retail gasoline and diesel prices also in the Western Balkan countries and prompted public opinion to question the pricing behaviors of oil companies. Kosova, in the period of 17 years, has gone from a post-conflict environment into a state which is considered to be under transition. It has passed the reconstruction period by orienting itself toward the economic development and European Integrations. Price and income elasticities of gasoline demand show whether the price policy, pursued by the Kosova government, can decrease the high gasoline consumption sufficiently or not. The high deficit of the current account of balance of payments is also a concern for the Kosova's economy; which is estimated up to $17.3 \%$ of the GDP after the foreign intervention. The deficit of current account is being considered is related to the energy dependency. Therefore, in order to overcome such problems, control over the gasoline demand is needed to control the deficit of current accounts.
\end{abstract}

Keywords: oil price, economic development, imports, trade deficit.

\section{Introduction}

Economic activities of Kosova prior to the conflict in 1999 were focused in the industry, energy, mines and metallurgy, construction materials and processing of agricultural products. During the 90's, the Kosova economy has marked a considerable decrease, initially due to a lack of required investments, secondly due to the devastation of production infrastructure and capacities devastated by the conflict of 1999. Therefore, Kosova as a post-war country, as well as with a subsequent transition phase, compared to the countries of the region, has also faces a very low level of foreign investments. In 1988, the general production of Kosova was dominated by industry, which comprised about $50 \%$ of the GDP, whereas agriculture comprised only about $20 \%$ of GDP2.

Economic development during the $2000-2013$ period was characterized by a small economic increase compared to the fairly low base at the commencement of the transition, as a generally unsustainable macroeconomic indicator, which may be observed from the table provided below. 
Table 1 Some key macroeconomic indicators

\begin{tabular}{|c|c|c|c|c|c|c|c|c|c|c|c|c|c|c|c|}
\hline $\begin{array}{l}\text { Subject } \\
\text { Descriptor }\end{array}$ & Units & 2000 & 2001 & 2002 & 2003 & 2004 & 2005 & 2006 & 2007 & 2008 & 2009 & 2010 & 2011 & 2012 & 2013 \\
\hline $\begin{array}{l}\text { Gross } \\
\text { domestic } \\
\text { product, } \\
\text { current } \\
\text { prices }\end{array}$ & $\begin{array}{l}\text { Billions } \\
\text { of } \\
\text { Euros }\end{array}$ & 2.417 & 2.831 & 2.862 & 2.967 & 2.912 & 3.003 & 3.120 & 3.461 & 3.883 & 4.070 & 4.402 & 4.815 & 5.059 & 5.327 \\
\hline $\begin{array}{l}\text { Inflation, } \\
\text { average } \\
\text { consumer } \\
\text { prices }\end{array}$ & $\begin{array}{l}\text { Percent } \\
\text { change }\end{array}$ & $\mathrm{n} / \mathrm{a}$ & 11.662 & 3.565 & 0.300 & -1.055 & -1.39 & 0.62 & 4.36 & 9.35 & -2.41 & 3.48 & 7.34 & 2.48 & 1.77 \\
\hline $\begin{array}{l}\text { Volume of } \\
\text { imports of } \\
\text { goods and } \\
\text { services }\end{array}$ & $\begin{array}{l}\text { Percent } \\
\text { change }\end{array}$ & $\mathrm{n} / \mathrm{a}$ & -17.68 & -4.87 & 13.81 & 23.52 & 4.28 & 6.36 & 17.71 & 18.66 & -2.56 & 3.97 & 8.56 & -14.65 & 1.67 \\
\hline $\begin{array}{l}\text { General } \\
\text { government } \\
\text { revenue }\end{array}$ & $\begin{array}{l}\text { Billions } \\
\text { of } \\
\text { Euros }\end{array}$ & 0.249 & 0.362 & 0.509 & 0.590 & 0.615 & 0.628 & 0.720 & 0.898 & 0.943 & 1.140 & 1.164 & 1.305 & 1.322 & 1.312 \\
\hline
\end{tabular}

Source: International Monetary Fund, World Economic Outlook Database, October 2014

Natural resources - Republic of Kosova has an area of $10.887 \mathrm{~km} /{ }^{2}$ and more than 2 million inhabitants (estimate of 1991)5, and an average density of 192 inhabitants per square kilometre, represents the areas with the highest density in the Balkan peninsula. The average salary is under 220 Euro. Kosova provides a modern system of telecommunications as well as young educated generations with a satisfactory level of informatics knowledge as well as higher levels of internet communications technologies, moreover, a considerable number of youth which is educated in western universities. Whereas, on the other hand, there is great interest from these generations to emigrate in order to find jobs due to the insufficient capacities of the Kosovar economy to generate new working positions.

There are few countries or administrative-political territories that have such a diversity of resources of mineral raw materials and energy resources in such a small area as does Kosova. Based on geological research, it has been concluded that Kosova has significant primary energy, metal and non-metal resources. Kosova has an immense quantity of coal and lignite; its reserves are estimated at 14 billion tons6. Research has concluded that there are significant reserves of minerals such as lead, zinc, (21.6 millions of tons), silver, gold, cadmium, bismuth, nickel (14 millions of tons), aluminium, chrome etc. Kosova also has large reserves of mineral non-metallic resources, especially magnesium (about 4.5 millions of tons), kaolin, benton, asbestos etc. The potential of natural resources of Kosova represents a good basis for its development in the future, however it is not being used to the extent required due to lack of investments. Due to its climate, good tradition that exists as well as diversity, from orchards, vegetables to wheat, this sector has been determined as one of the sectors of the highest priority. Kosova is known for the production of wheat, cabbages, potatoes, fruits, wines, mushrooms, tobacco etc. However, the agriculture of Kosova is characterized by small farms as well as low production capabilities. 


\section{Literature Review}

There are a large number of studies on the demand for gasoline with different methods. In recent years, Dahl (2012), has classified the major studies, depending on the model and the estimates. So a review of the related studies improves the outlook on the subject, before dealing with the studies in detail.

Dahl and Sterner (1991) reviewed 97 studies on the demand for gasoline, the most recent published in 1988. Despite the use of different estimation methods, all studies have estimated real price and real income as a former explanatory variables. Because of the various models enormously in the studies, they broke the models into ten "distinct groups" that show results almost unique. They argue that gasoline demand is mostly inelastic to price and income. Moreover, they argue that by correlating the first model with the second model of the ten groups led elasticity intermediate stroke [8]. There are newer like this poll.

Espey (1998) examined 101 studies on the demand for gasoline, performed within the period from 1966 to 1997 with data from 1929 to 1993. According to the survey, the functional forms and countries are very different, but they all use real price and real income as explanatory variables. Thanks to the wide range of elasticity in the previous studies, has classified the short run and the long run average estimates in different groups [9]. Similarly, Dahl (2012) has classified the price of gasoline demand and income elasticity of previous studies with static models in many groups. Overall, the most frequent elasticity imply that the demand for gasoline is maily price-inelastic and income in both Espey (1998) and Dahl (2012). Meta-analysis, as Dahl (2012), Dahl and Sterner (1991), and Espey (1998), dealing with the issue as a whole.

There are many studies that cover the literature in general, but by reviewing some studies they are more focused on industrialized countries. Sene (2012), Akinboade et al. (2008), and Ramanathan (1999) focuses on a few countries in the developing world. Sene (2012) estimated the short and long run price and income elasticities in Senegal, using the linear model log. He found that the demand for gasoline is inelastic because petroleum products are not substitutes. Akinboade et al. (2008) estimated price and income elasticity of demand for gasoline with Autoregressive Distributed Lag Model (ARDL) in South Africa. They showed that gasoline demand is inelastic in the countries. Ramanathan (1999) took cointegration equation and Error Correction Model (ECM) to estimate the elasticity of demand for gasoline in India through two intervals, short and long term, as well as the speed of adjustment. Although the demand for gasoline is estimated income elastic, is inelastic in both bays. The speed of adjustment is low, at $28 \%$, that of Baranzini and Weber (2013). Eltony and Al-Mutairi (1995) have argued that the demand for gasoline is the price and income inelastic in Kuwait, as development and production of oil country. Some studies focus on oil-producing countries such as Iran, which have relatively low price and high consumption of gasoline, and can not be considered as a special case of developing countries.

The analysis of gasoline demand in not oil-producing countries it is still a field of study not explored in details. 


\section{Discussion}

Dramatic fluctuations of recent international oil prices have caused governments and the public to pay more attention to the adjustment of gasoline prices. Based on the monthly data between 2014M1 and 2014M12, this study employed an asymmetric ECM to estimate the petrol models and price adjustment of retail sales of diesel in Kosova. In this study, oil prices were considered the main cost of refining gasoline and diesel fuel, and had a significant relationship of long-term balance with petrol and diesel prices. An examination of the dynamic adjustments of petrol and diesel prices showed that the asymmetric adjustments were common and that the price asymmetry was especially short term. Despite the slight difference of pricing adjustments in several countries and petrol and diesel for cars, most of the price adjustments were closer to the political-economic asymmetry proposed by Kirchgässner and Kubler (1992) than the trends indicated by many other studies. In other words, even if markets gasoline and diesel marked with imperfect competition, government intervention seems to dominate the adjustments gasoline and diesel prices in the Republic of Kosova as discussed in this study.

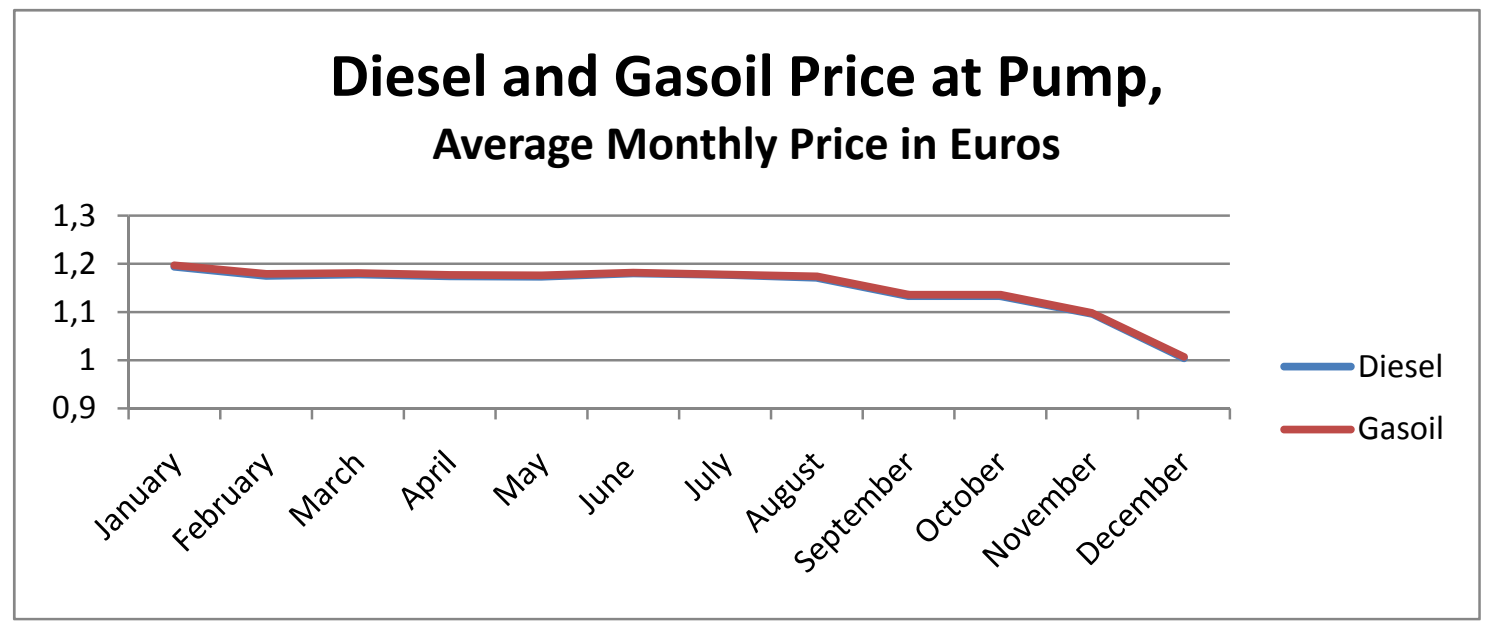




\begin{tabular}{|c|c|c|}
\hline $\begin{array}{c}\text { Table } 1 \text { Average Monthly } \\
\text { Prices (2014) }\end{array}$ & Diesel & Gasoil \\
\hline January & 1,194 & 1,197 \\
\hline February & 1,175 & 1,179 \\
\hline March & 1,178 & 1,181 \\
\hline April & 1,174 & 1,177 \\
\hline May & 1,173 & 1,176 \\
\hline June & 1,18 & 1,182 \\
\hline July & 1,177 & 1,178 \\
\hline August & 1,171 & 1,174 \\
\hline September & 1,133 & 1,136 \\
\hline October & 1,133 & 1,136 \\
\hline November & 1,096 & 1,098 \\
\hline December & 1,004 & 1,007 \\
\hline
\end{tabular}

In this study, an augmented Dicky-Fuller (ADF) test (including the intercept and time trend) was performed.

The results indicated that none of the variables could reject the null hypothesis, which contended that the unit root existed. After taking the first-order difference of the variables, the same testing procedure was used, and the results showed that all variables significantly rejected the null hypothesis regarding the existence of unit roots, indicating that levels and First Differences are a $\mathrm{I}(1)$ series (the unit root test results are shown in Table 2).

Table 2. ADF tests

\begin{tabular}{|lcc|} 
& Levels & First Difference \\
\hline Retail gasoline prices & 0.461 & -5.470 \\
\hline Retail diesel prices & -2.314 & -7.201 \\
\hline
\end{tabular}

1. The numbers in this table are the $\mathrm{t}$ statistics of $\mathrm{ADF}$ regression, including both the intercept and time trend. The optimal lags of ADF regression that were determined using the Schwarz Criterion (maximum lags $=12)$.

2. The null hypothesis of a unit root is rejected at the 5\% both for levels and First Difference.

OLS was then employed to estimate Equation (1), and ADF tests (excluding the intercept and time trend) were performed on the residuals.

The results are shown in Table 2. First, all regression residuals significantly rejected the unit-root null hypothesis at 5\% significance level, indicating a cointegration relationship between retail gasoline and diesel prices and oil prices in various countries. Estimation 
results for the cointegration relationship showed that oil prices generally had high longterm pass-through to diesel prices; For example, a 1\% oil price increase resulted in $0.461 \%$ and $2.314 \%$ long-term increases in the retail gasoline and diesel prices, respectively, possibly because differing gasoline and diesel refining processes caused different levels of dependence on crude oil. In addition, the estimation values for both gasoline and diesel prices were, in declining order indicating that retail gasoline (diesel) pricing in is determined, to the highest degree among the four countries, by non-oil price costs, such as costs for labor, rent, and placement or allocation processes, whereas pricing in is the least so.

The speed of adjustment is slow, at $-0.19,19 \%$ of the adjustment implying gasoline consumption occurs during the first year. So imbalance lasts for more than five years to achieve long-run equilibrium.

Consequently, the demand for gasoline responds to price and income changes slightly and slowly, relatively the same results of previous studies.

\section{Conclusions}

The gasoline demand responds to price and income changes slightly and slowly in Kosova during 2002-2013.

The gasoline demand is price and income inelastic in all the three intervals which characterizes gasoline as a necessary good with no close substitutes. Not only is the response magnitude of the gasoline consumption to price and income small but also the response speed is slow because the adjustment velocity is low. So price pol- icy reduces the gasoline consumption ineffectively with a long delay. Even more, the price policy may be dominated by income rise in Kosova as a developing country.

Increasing effect of income growth can overtake the decreasing effect of the price policy. The economy of Kosova, on one hand, is expected to grow because developing economies are less than their potential level. The income elasticity of gasoline demand, on the other hand, is more than the price elasticity. Therefore, other alternatives, besides the price policy, should be developed to reduce the negative consequences of gasoline consumption, for example, supplying more environmentally friendly substitutes, more reliable public transportation systems, and setting higher environmental standards for industries, especially for car factories.

As a future study, estimating the elasticities of these factors can guide the governors and policy makers to pursue the most efficient policies.

\section{References}

Akinboade, O.A., Ziramba, E. and Kumo, W.L. (2008) The Demand for Gasoline in South Africa: An Empirical Anal- ysis Using Co-Integration Technique. Energy Economics, 30, 3222-3229. http://dx.doi.org/10.1016/j.eneco.2008.05.002

Al-Gudhea, S., Kenc, T., \& Dibooglu, S. (2007). Do Retail Gasoline Prices Rise More Readily than They Fall? A Threshold Cointegration Approach. Journal of Economics and Business, 59, 560-574. http://dx.doi.org/10.1016/j.jeconbus.2006.10.002 
Alves, D.C.O. and Bueno, R.D. (2003) Short-Run, Long-Run and Cross Elasticities of Gasoline Demand in Brazil. Energy Economics, 25, 191-199. http://dx.doi.org/10.1016/S0140-9883(02)00108-1

Bachmeier, L. J., \& Griffin, J. M. (2003). New Evidence on Asymmetric Gasoline Price Responses. Review of Economics and Statistics, 85, 772-776. http://dx.doi.org/10.1162/003465303322369902

Bacon, R. W. (1991). Rockets and Feathers: The Asymmetric Speed of Adjustment of U.K. Retail Gasoline Prices to www.sciedu.ca/ijfr International Journal of Financial Research Vol. 4, No. 3; 2013 Cost Changes. Energy Economics, 13, 211-218. http://dx.doi.org/10.1016/0140-9883(91)90022-R

Baranzini, A. and Weber, S. (2013) Elasticities of Gasoline Demand in Switzerland. Energy Policy, 63, 674680. http://dx.doi.org/10.1016/j.enpol.2013.08.084

Bettendorf, L., van der Geest, S. A., \& Varkevisser M. (2003). Price Asymmetry in the Dutch Retail Gasoline Market. Energy Economics, 25, 669-689. http://dx.doi.org/10.1016/S0140-9883(03)00035-5

Bhattacharyya, S.C. and Blake, A. (2009) Domestic Demand for Petroleum Products in MENA Countries. Energy Pol- icy, 37, 1552-1560. http://dx.doi.org/10.1016/j.enpol.2008.12.028

Borenstein, S., Cameron, A. C., \& Gilbert, R. (1997). Do Gasoline Prices Respond Asymmetrically To Crude oil Price Changes? The Quarterly Journal of Economics, 305-339.

Chen, L. H., Finney, M., \& Lai, K. S. (2005). A Threshold Cointegration Analysis of Asymmetric Price Transmission from Crude Oil to Gasoline Prices. Economics Letters, 89, 233-239. http://dx.doi.org/10.1016/j.econlet.2005.05.037

Chou, K. W. (2012). Price Adjustment in Taiwan Retail Gasoline Market. International Journal of Economics and Finance, 4(7), 132-140. http://dx.doi.org/10.5539/ijef.v4n7p132

Dahl, C. and Sterner, T. (1991) Analysing Gasoline Demand Elasticities: A Survey. Energy Economics, 13, 203-210. http://dx.doi.org/10.1016/0140-9883(91)90021-Q.

Dahl, C.A. (2012) Measuring Global Gasoline and Diesel Price and Income Elasticities. Energy Policy, 41, 213. http://dx.doi.org/10.1016/j.enpol.2010.11.055

Eltony, M.N. and Al-Mtairi, N.H. (1995) Demand for Gasoline in Kuwait: An Empirical Analysis Using Cointegration Techniques. Energy Economics, 17, 249-253. http://dx.doi.org/10.1016/01409883(95)00006-G

Engel, R.F. and Granger, C.W.J. (1987) Co-Intergration and Error Correction: Representation,

Estimation, and Testing. Econometrica, 55, 251-276. http://dx.doi.org/10.2307/1913236

Engle, R. F., \& Granger, C. W. J. (1987). Co-Integration and Error Correction: Representation, Estimation, and Testing. Econometrica, 55, 251-276.

Espey, M. (1998) Gasoline Demand Revisited: An International Meta-Analysis of Elasticities. Energy Economics, 20, 273-295. http://dx.doi.org/10.1016/S0140-9883(97)00013-3.

European Gasoline Markets. Energy Economics, 25, 175-190. http://dx.doi.org/10.1016/S01409883(02)00102-0

Frey, G., \& Manera, M. (2007). Econometric Models of Asymmetric Price Transmission. Journal of Economic Surveys, 21, 349-415.

Galeotti, M., Lanza, A., \& Manera, M. (2003). Rockets and Feathers Revisited: An International Comparison on

Godby, R., Lintner, A. M., \& Wandschneider, T. S. B. (2000). Testing for Symmetric Pricing in the Canada Retail Gasoline Market. Energy Economics, 22, 349-368. http://dx.doi.org/10.1016/S01409883(99)00030-4

Granger, C. W. J., \& Lee, T. H. (1989). Investigation of Production, Sales and Inventory Relationships Using Multicointegration and Non-Symmetric Error Correction Models. Journal of Applied Economics, 4, S145-S159. http://dx.doi.org/10.1002/jae.3950040508

Gujarati, D.N. (2004) Basic Econometrics. 4th Edition, MC-Graw-Hill, Classical Normal Linear Regression Model (CNLMR), Boston, Massachussets, 107-118.

Johnson, R. N. (2002). Search Costs, Lags and Prices at the Pump. Review of Industrial Organization, 20, 33-50.

Karrenbrock, J. D. (1991). The Behavior of Retail Gasoline Prices: Symmetric or Not? Federal Reserve Bank of St.

Kirchgassner, G., \& Kubler, K. (1992). Symmetric or Asymmetric Price Adjustment in the Oil Market: An Empirical Analysis of the Relations between International and Domestic Prices in the Federal Republic of Germany 1972-1989. Energy Economics, 14, 171-185.

Louis, 73, 19-29. 
Manning, D. N. (1991). Petrol Prices, Oil Price Rises and Oil Price Falls: Some Evidence for the UK since 1972. Applied Economics, 23, 1535-1541.

Ministry of Trade and Industry, Bulletin, Prishtina, 2013

Ministry of Trade and Industry, Annual Report, Prishtina, 2013

Ministry of Trade and Industry, Trend of Foreign Investments in Kosova, 2013

Ministry of Environment and Spatial Planning, Kosova Institute for the Protection of Nature, Natural, Heritage Values of Kosova, 2005, Prishtina.

Ministry of trade and Industry, Country Fact Sheet Kosova, 2013, Prishtina.

Newey, W. K., \& West, K. (1987). A Simple Positive Semi-Definite Heteroskedasticity and Autocorrelation Consistent Covariance Matrix. Econometrica, 55, 703-708.

Radchenko, S. (2005). Oil Price Volatility and the Asymmetric Response of Gasoline Prices to Oil Price $\begin{array}{llll}\text { Increases and Decreases. Energy } & \text { Economics, 27, }\end{array}$ http://dx.doi.org/10.1016/j.eneco.2005.06.001

Radchenko, S., \& Shapiro, D. (2011). Anticipated and Unanticipated Effects of Crude Oil Prices and Gasoline Inventory Changes on Gasoline Prices. Energy Economics, 33, 758-769. http://dx.doi.org/10.1016/j.eneco.201.01.002

Ramanathan, R. (1999) Short- and Long-Run Elasticities of Gasoline Demand in India: An Empirical Analysis Using Cointegration Techniques. Energy Economics, 21, 321-330. http://dx.doi.org/10.1016/S0140-9883(99)00011-0

Rao, B.B. and Rao, G. (2009) Cointegration and the Demand for Gasoline. Energy Policy, 37, 3978-3983. http://dx.doi.org/10.1016/j.enpol.2009.04.046

Sa'ad, S. (2009) An Empirical Analysis of Petroleum Demand for Indonesia: An Application of the Cointegration Ap- proach. Energy Policy, 37, 4391-4396. http://dx.doi.org/10.1016/i.enpol.2009.05.058

Sene, S.O. (2012) Estimating the Demand for Gasoline in Developing Countries: Senegal. Energy Economics, 34, 189-194. http://dx.doi.org/10.1016/j.eneco.2011.04.014.

Tappata, M. (2009). Rockets and Feathers: Understanding Asymmetric Pricing. RAND Journal of Economics, 40, 673-687. http://dx.doi.org/10.1111/j.1756-2171.2009.00084.x

Taylor, B.N. and Thompson, A. (2008) The International System of Units (IS), National Institute of Standards and Technology. US Department of Commerce, 37.

Verlinda, J. A. (2008). Do Rockets Rise Faster and Feathers Fall Slower in an Atmosphere of Local Market Power? Evidence from the Retail Gasoline Market. The Journal of Industrial Economics, 56, 581-612. http://dx.doi.org/10.1111/j.1467-6451.2008.00351.x

Wadud, Z., Graham, D.J. and Noland, R.B. (2009) A Cointegration Analysis of Gasoline Demand in the $\begin{array}{llll}\text { United States. } & \text { Applied }\end{array}$ http://dx.doi.org/10.1080/00036840701477306

Wu, J. H., Huang, Y. L., \& Liu, C. C. (2011). Effect of Floating Price Policy: An Application of System Dynamics on Oil Market after Liberalization. Energy Policy, 39, 4235-4252. http://dx.doi.org/10.1016/j.enpol.2011.04.039 